\title{
The Grey Seal (Halichoerus grypus) as a Predator of Harbour Porpoises (Phocoena phocoena)?
}

\author{
Jan Haelters, ${ }^{1}$ Francis Kerckhof, ${ }^{1}$ Thierry Jauniaux, ${ }^{2}$ and Steven Degraer ${ }^{1}$ \\ ${ }^{1}$ Royal Belgian Institute of Natural Sciences (RBINS), Management Unit of the North Sea Mathematical Models (MUMM), \\ Gulledelle 100, B-1200 Brussels and $3^{e}$ en $23^{\text {ste }}$ Linieregimentsplein, B-8400 Ostend, Belgium \\ E-mail: j.haelters@mumm.ac.be \\ ${ }^{2}$ Department of Pathology, Veterinary College, Sart Tilman Bat B43, B-4000 Liège, Belgium
}

\begin{abstract}
In September 2011, two harbour porpoises (Phocoena phocoena) presenting extensive traumatic lesions washed ashore in Belgium. Similar lesions, with large parts of skin and blubber missing, had not been recorded before on harbour porpoises in Belgium but were recently observed in a number of cases in neighbouring countries. We compared the lesions with the mouth and teeth structure of possible predators. The circumstances of the strandings, the observations during the necropsies, and the results of seal skull investigations pointed towards seals, presumably grey seals (Halichoerus grypus), as the prime suspects for having caused the death of both harbour porpoises. Although purely aggressive behaviour cannot be completely excluded, predation is considered most likely as part of the skin and blubber tissue of the harbour porpoises was missing. The grey seal is an opportunistic predator, feeding on a variety of fish and cephalopods, and occasionally even on crustaceans and seabirds, but predation on harbour porpoises, or any other marine mammal, had to our knowledge never been described. This finding might shed a new light on the cause of death of some of the other mutilated harbour porpoises recently stranded on southern North Sea beaches, and it presents a case of a change in the feeding strategy of a top predator.
\end{abstract}

Key Words: harbour porpoise, Phocoena phocoena, grey seal, Halichoerus grypus, predation, Belgium

\section{Introduction}

The harbour porpoise (Phocoena phocoena) is the most common marine mammal in Belgian waters, with seasonally average densities of up to more than one animal $/ \mathrm{km}^{2}$ (Haelters \& Camphuysen, 2009; Haelters et al., 2011). In the southern North Sea, this species co-occurs with a number of other marine mammals: the harbour seal (Phoca vitulina), the grey seal (Halichoerus grypus), and the white-beaked dolphin (Lagenorhynchus albirostris) (Reijnders et al., 1997; Camphuysen \& Peet, 2006; Management Unit of the North Sea Mathematical Models [MUMM], unpub. data). Other large predators, such as a number of odontocetes (other than the white-beaked dolphin); Arctic pinnipeds such as the hooded seal (Cystophora cristata) and harp seal (Pagophilus groenlandicus); and large sharks such as the porbeagle shark (Lamna nasus), thresher shark (Alopias vulpinus), Greenland shark (Somniosus microcepha$l u s$ ), and blue shark (Prionace glauca) only occur in the southern North Sea as vagrants (MUMM, unpub. data). As a number of marine mammal species share the same habitat and food resources, it is likely that occasionally interspecific interactions occur. Reports have been made of lethal interactions of harbour porpoises with bottlenose dolphins (Tursiops truncatus) (Ross \& Wilson, 1996; Barnett et al., 2009) and nonlethal interactions of harbour porpoises with whitebeaked dolphins (Haelters \& Everaarts, 2011).

In September 2011, two harbour porpoises exhibiting similar extensive lesions washed ashore in Belgium. The nature of the lesions on both animals clearly differed from lesions observed on any of the more than 600 harbour porpoises stranded on Belgian beaches during the last decade, including bycaught as well as animals that had died naturally. The lesionsat least superficially - were similar to those in recent cases of mutilated and "unaccountable" carcasses of harbour porpoises from other locations around the southern North Sea (Leopold \& Camphuysen, 2006; Camphuysen \& Oosterbaan, 2009). Given the fact that the lesions could be interpreted as bite marks, we investigated whether the cause of death of both mutilated harbour porpoises could indeed be attributed to lethal interactions with a large marine predator. We aimed at identifying the species most likely to be responsible, the reasons behind the behaviour, and its possible consequences. 


\section{Materials and Methods}

Investigation of Mutilated Harbour Porpoises

We investigated two freshly dead harbour porpoises, described as in Condition Code 2 (very fresh, no decomposition; Jauniaux et al., 2002), that washed ashore on the Belgian coast in September 2011. Both animals were missing large strips of skin and blubber. The first harbour porpoise (Animal 1) was found on 3 September 2011 at the town of Oostende (Raversijde), located centrally at the Belgian coast (Figure 1). The second harbour porpoise (Animal 2) was found on 24 September 2011 at Knokke-Heist, Belgium's most easterly coastal community (Figure 1). At both occasions, the meteorological conditions, with a low wind speed and a calm sea (sea state: $0-1)$, together with the very fresh condition of both animals, indicated that death had occurred shortly before their stranding and very close inshore. Both animals were found near the low water mark and not near the high water line which is usually the case for floating carcasses. Several witnesses were present, and the strandings were directly reported to the proper authorities. Both animals were frozen immediately after their collection from the beach and slowly defrosted before the necropsy. The necropsies of the animals were performed according to a standardised methodology (Jauniaux et al., 2002), and they were fully described and documented with photographs.



Figure 1. Location of the strandings of the two harbour porpoises at the Belgian coast (Animals 1 and 2, respectively) within the North Sea (inset); the lines indicate the delimitation of Belgian waters.

\section{Aggressor Identification}

Given the nature of the lesions on both harbour porpoises (see Figures 2 through 11), we could immediately exclude an interaction with other odontocetes, such as the bottlenose dolphin and the killer whale (Orcinus orca), or with large pelagic sharks. These predators occur only very rarely in Belgian waters, and they would have left very different marks than the ones observed (e.g., no canine insertions). No predators occurring in the southern North Sea other than seals are capable of inflicting the types of injuries present on both harbour porpoises. To investigate this further, we made measurements of the teeth structure of 52 harbour seal skulls (12 females, 9 males, 31 unknown sex) and 87 grey seal skulls (36 females, 34 males, 17 unknown sex) available from the Royal Belgian Institute of Natural Sciences; Ghent University (Belgium); the Netherlands Centre for Biodiversity Naturalis; the Muséum National d'Histoire Naturelle (France); the Centre de Recherche sur les Mammifères Marins, University of La Rochelle (France); and the Natural History Museum (UK). Only skulls that originated from animals collected in the North Sea (including the Channel) and the adjacent Atlantic Ocean (British Isles, French Atlantic coast) were considered, while for the harbour seal, three specimens originating from Iceland also were included. In total, 20 skulls from animals that died in zoos were kept in the analysis as they were thought or known to come from animals from the same area.

We measured inter-tooth distances of canine teeth in the mandible and maxilla. The measurements were made at the midpoint of the apex of the teeth. In cases where the mandibular symphysis was not intact, measurements of the intercanine distance were retained if a high degree of confidence existed relating to their accuracy. Excessive antemortem wear or postmortem loss of teeth, as well as the unavailability of the mandible in many cases, meant that on some skulls no measurements were possible for the maxilla or mandible. Eventually, the following measurements were attained:

- 52 and 41 inter-canine distances of the maxilla and the mandible of harbour seals, respectively

- 76 and 37 inter-canine distances of the maxilla and the mandible of grey seals, respectively

\section{Results}

In both harbour porpoises, sero-haemorrhagic froth was exuding from their blowholes, and they were still bleeding at the time of their collection on the beach. Typical bycatch lesions such as superficial net marks around snout and fins, pectoral fin lacerations, or open wounds near the snout (Haelters \& Camphuysen, 2009) were not present on either of the animals. However, the necropsy revealed that both animals had bilateral hyphema 




Figure 2. Left lateral view (top), ventral view (middle), and right lateral view (bottom) of Animal 1 before the start of the necropsy, illustrating the extensive lesions and the disappearance of pieces of skin and blubber

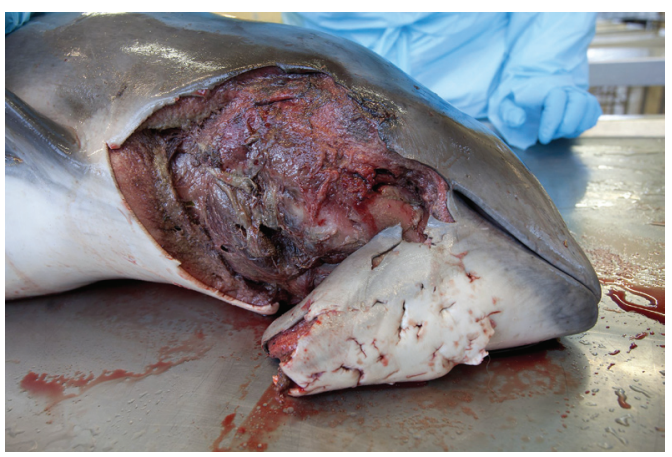

Figure 3. External view of the right lateral side of Animal 1 before the necropsy, showing a large, partly detached flap of skin and blubber with numerous irregular cuts

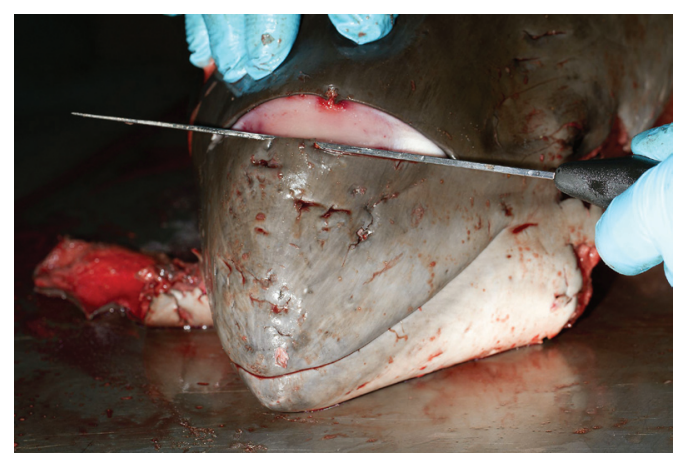

Figure 4. Cutting through the melon of Animal 1, showing a large number of haemorrhagic lesions



Figure 5. External view of the left lateral side of Animal 1 before the necropsy, showing the disappearance of two strips of skin and blubber, perpendicular to each other, with, at their onset, two parallel, slightly curved incisions 5.2 (A) and $5.5 \mathrm{~cm}(\mathrm{~B})$ apart, respectively

(blood in the eye) and that abundant sero-haemorrhagic froth was present in the airways, which is frequently observed after drowning.

\section{Animal 1}

Animal 1 was a juvenile male of $1.27 \mathrm{~m}$. Its remains weighed $28.0 \mathrm{~kg}$. Its blubber thickness, measured dorsally near the anterior side of the dorsal fin (Lockyer, 1995; Lockyer et al., 2003), was $15 \mathrm{~mm}$, consistent with an intermediate nutritional condition.

The most extensive external lesions were skin and blubber torn from the largest part of the lateral and ventral side of the head, from the eyes downward, and from the posterior edges of the mouth to the proximal part of the pectoral fins (Figure 2). A large flap of skin and blubber hung partly detached at the right side of the head, laterally to ventrally. It was still connected to the head in the submandibular region and showed parallel, arched, and finely serrated edges and numerous irregular cuts that were haemorrhagic in the blubber layer (Figure 3). On the melon, there were a large number of puncture lesions present, of which four were in the form of a volcano with an outer and inner diameter of 12 and $3 \mathrm{~mm}$, respectively. Cutting into these lesions revealed haemorrhagic tissue and a cavity with a diameter of $5 \mathrm{~mm}$ (Figure 4). On the left side of the head, two strips of skin and blubber, perpendicular to each other, were missing. At their onset, both strips had two parallel, slightly curved incisions, separated by $5.2 \mathrm{~cm}$ (cut under the eye) and $5.5 \mathrm{~cm}$ (cut above the left pectoral fin) (Figure 5). The cut above the pectoral fin was $18 \mathrm{~cm}$ long at the posterior side and $9 \mathrm{~cm}$ on the anterior side. The edges of the lesions were finely serrated (Figure 6). Two 




Figure 6. The edges of the lesion on the left lateral side of Animal 1, above the left pectoral fin, showing (as all lesions on Animal 1 did) ragged edges

smaller, parallel, and slightly curved cuts above the left eye, $2 \mathrm{~cm}$ long and $1 \mathrm{~cm}$ apart, had haemorrhagic tissue below. In the intermandibular region, a haemorrhagic depression was present.

The internal examination of Animal 1 revealed a slight trematode infestation of the biliary ducts, a moderate to severe nematode infestation in the airways and pulmonary blood vessels, along with foci of chronic pneumonitis. The lungs, trachea, and larynx were severely congested. Abundant sero-haemorrhagic froth was present in the airways. The stomach contained fresh gobies (Pomatoschistus $\mathrm{sp}$.). Three partly digested gobies were observed in the oesophagus. Under microscopic investigation, haemorrhages of the blubber, characterised by the presence of red blood cells between adipocytes, were observed for some of the puncture skin lesions (Figure 4).

\section{Animal 2}

Animal 2 was a juvenile male of $1.14 \mathrm{~m}$. Its remains weighed $18.3 \mathrm{~kg}$. The dorsal blubber thickness measured $7 \mathrm{~mm}$, consistent with a poor nutritional condition. A few small acute to chronic ulcers were present on the body; some of these were infested with whale lice (Isocyamus delphinii) (Crustacea, Amphipoda), which were still alive at the time the harbour porpoise was collected from the beach.

The most extensive external lesions in Animal 2 were the lack of skin and blubber from a large part of the ventral side, from the head up to the genital region over a length of $56 \mathrm{~cm}$ (Figure 7). The sublaryngeal tissue was haemorrhagic as was a region with a diameter of $5 \mathrm{~cm}$ dorsally of the left eye. On the left lateral side, from the proximal part of the pectoral fin towards the caudal end, the skin and blubber layer were detached from the underlying muscle layer and rib cage in a region of $40 \mathrm{~cm}$ long by $15 \mathrm{~cm}$ wide. A long, partly detached flap of skin and blubber with finely serrated edges extended from the genital region towards the head. A deeper incision, provoking intestinal protrusion, was present in the ventral region near the genital slit. On the left, the lesions extended laterally, between the proximal part of the left pectoral fin and the eye. On the right side, the lesions extended caudally of the right pectoral fin, where they showed an M-shaped cut with two parallel, slightly curved incisions, their tops spaced out $6.0 \mathrm{~cm}$ (Figure 8). A $20-\mathrm{cm}$-long Y-shaped laceration with irregular edges extended from the dorsal to the right lateral side behind the head, above the implantation of the right pectoral fin (Figure 9). This open lesion did not cause tissue loss, and the distance between the dorsal branches of this cut, with the original skin reconstructed, measured $4.5 \mathrm{~cm}$. At a few $\mathrm{cm}$ caudally from this Y-shaped cut, several small lacerations were present, all around $1 \mathrm{~cm}$ in length and with irregular borders. On the left ventral side of the abdomen, shallow parallel incisions were present at two locations a few $\mathrm{cm}$ away from each other. In the most lateral location, these parallel incisions spanned $4.0 \mathrm{~cm}$. On the left side of the tailstock, a large number of irregular cuts were noticed, which were described as two superimposed and slightly offset U-forms (Figure 10). Incisions into these marks revealed haemorrhagic tissue. On the corresponding position at the right side of the tailstock, irregular shallower incisions set in a U-form were present. On the right side of the tailstock, to the anterior side of the lesions set in a U-form, two lacerations ( 4.0 to $5.0 \mathrm{~cm}$ apart and 2.5 and $4.5 \mathrm{~cm}$ long, respectively), with irregular edges and penetrating the flesh, were present. A shallower wound, only slightly touching the flesh, was visible in between them (Figure 11).

Other observations included subcutaneous oedema; a moderate nematode infestation in the airways and pulmonary blood vessels; abundant sero-haemorrhagic froth in the airways; a severe congestion of both lungs, airways, and larynx; and meningeal congestion. The stomach contained fresh fish: gobies and whiting (Merlangius merlangus) and grey shrimp (Crangon crangon). In the oesophagus, a small number of goby otoliths and one fresh goby were observed.

\section{Possible Aggressor Characterisation}

The distance between the canine teeth in the maxilla of harbour seals ranged from 1.5 to $4.8 \mathrm{~cm}$, while in the mandible it ranged from 1.4 to $4.2 \mathrm{~cm}$ (Figure 12). The skull with the largest inter-canine distance in its maxilla lacked the mandibula. In the grey seal skulls, the distance between the canine teeth in the maxilla ranged from 2.2 to $7.1 \mathrm{~cm}$, while in the mandible it ranged from 1.9 to $6.0 \mathrm{~cm}$ (Figure 13). 


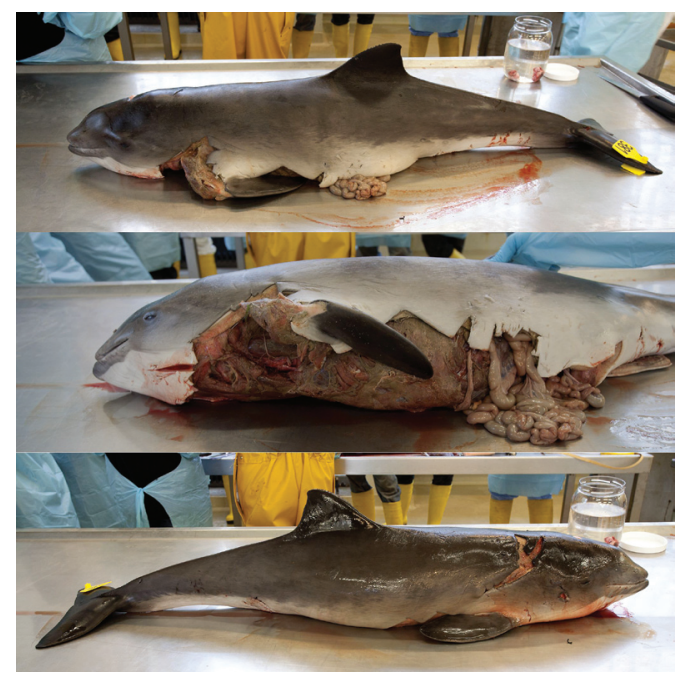

Figure 7. Left lateral view (top), ventral view (middle), and right lateral view (bottom) of Animal 2 before the start of the necropsy, illustrating the extensive lesions and the disappearance of most of the skin and blubber on the ventral side

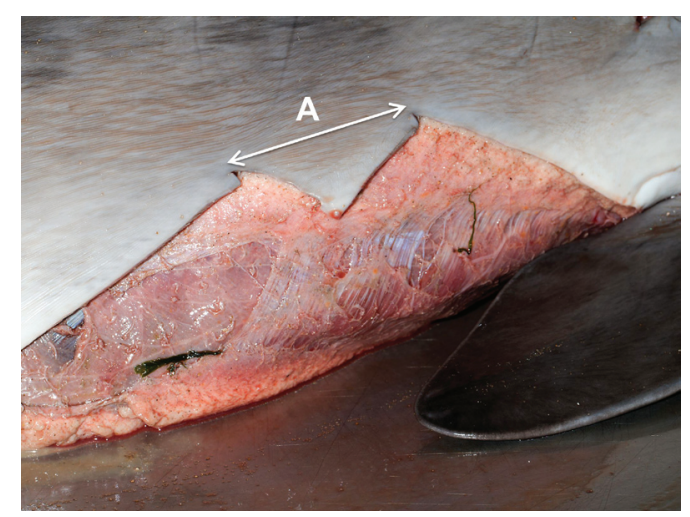

Figure 8. Lesion on the right ventral-lateral side of Animal 2 showing an M-shaped cut with a set of parallel, slightly curved incisions $6.0 \mathrm{~cm}$ apart (A)

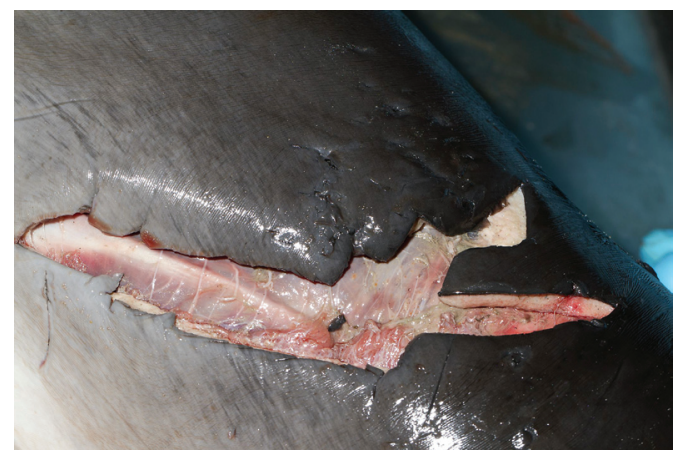

Figure 9. Y-shaped cut with irregular edges on the right lateral-dorsal side of Animal 2

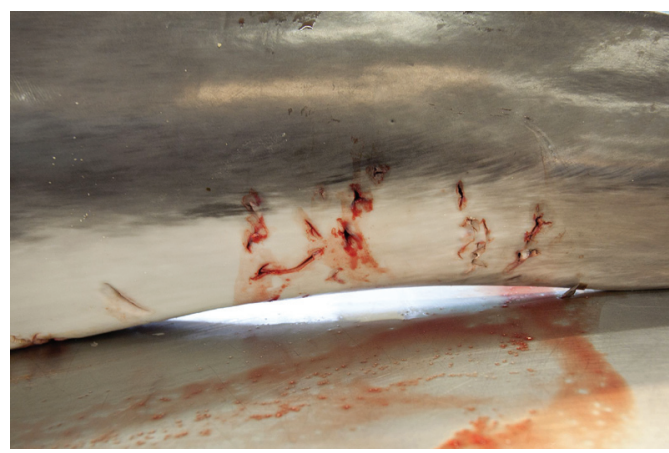

Figure 10. View of the left side of the tailstock of Animal 2, with a series of cuts in two superimposed and shifted U-forms

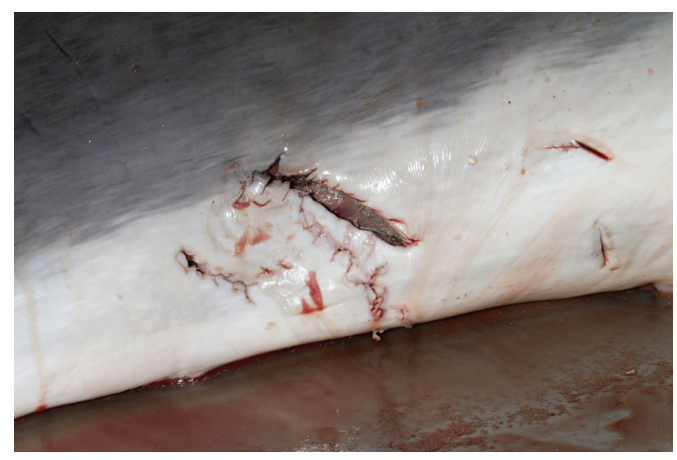

Figure 11. On the right side of the tailstock of Animal 2, towards the proximal side of the lesion on the left side of the tailstock, two parallel lacerations, cutting into the flesh and with irregular edges, were present, next to a third shallower one

\section{Discussion}

\section{Cause of Death and Aggressor Identification}

Both harbour porpoises were very fresh upon collection, and they had full stomachs, atypical for animals that died of disease or starvation. From their condition and the many haemorrhages encountered, it can be concluded that they had died an acute and traumatic death shortly before their stranding and, thus, close inshore. In both animals, several lesions were initiated by two short parallel and slightly curved incisions, which continued in a straight rupture of skin and blubber. In Animal 1, the distance between these incisions, appearing to be canine teeth marks, was 5.2 and $5.5 \mathrm{~cm}$, respectively. In Animal 2, the distance between the presumed canine teeth marks was 6.0, 4.5 , and 4.0 to $5.0 \mathrm{~cm}$, respectively. This distance could have changed slightly after the rupture of skin and blubber. Also in Animal 2, rake marks of what seemed to be traces of incisor teeth were present. The lesion on the tailstock of Animal 2 


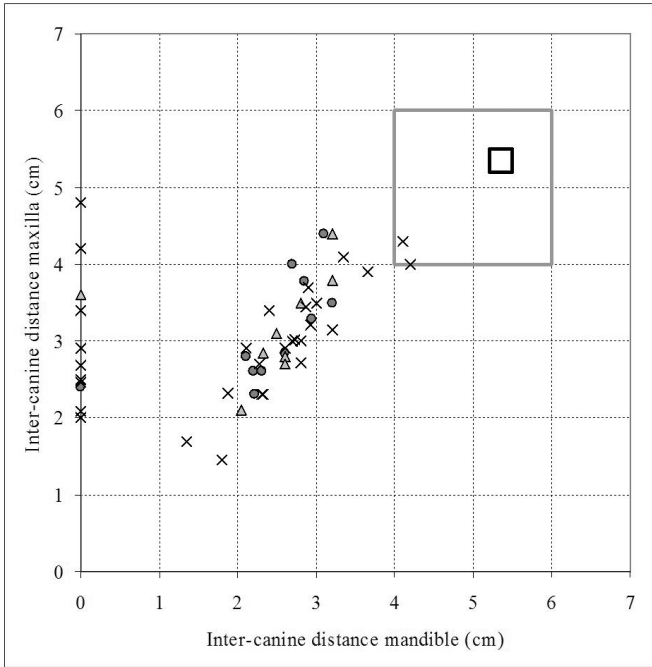

Figure 12. Inter-canine distance in the mandible ( $\mathrm{x}$-axis) and maxilla (y-axis) of harbour seal skulls: females (circles), males (triangles), and skulls originating from animals with an unknown sex (crosses); distances indicated on the y-axis taken from skulls of which the inter-canine distance in the mandible could not be measured. Black and grey squares: range of the presumed canine teeth lesions on Animals 1 and 2 , respectively.

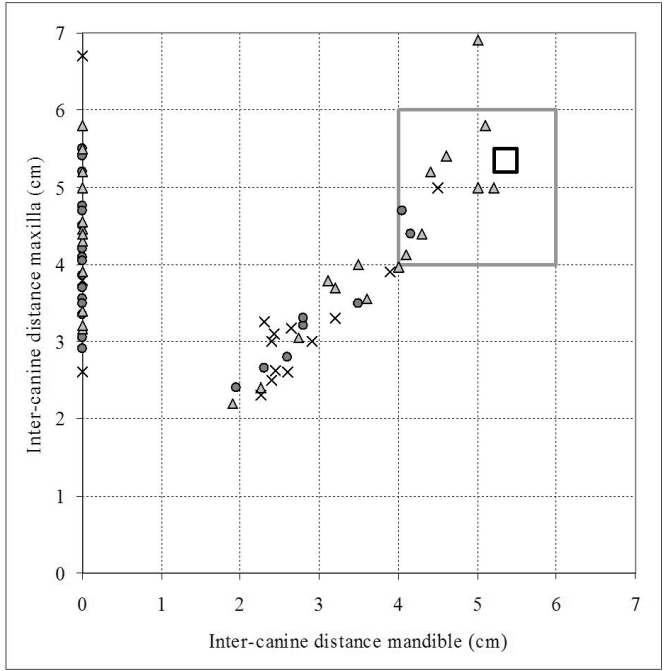

Figure 13. Inter-canine distance in the mandible (x-axis) and maxilla (y-axis) of grey seal skulls: females (circles), males (triangles), and skulls originating from animals with an unknown sex (crosses); distances indicated on the y-axis taken from skulls of which the inter-canine distance in the mandible could not be measured. Black and grey squares: range of the presumed canine teeth lesions on Animals 1 and 2 , respectively. can be described as two superimposed bite marks. Random, smaller, irregular lesions and puncture lesions were present on both animals and probably originated from teeth or claws.

Together with the absence of typical bycatch marks and the disappearance of large parts of skin and blubber tissue, the bite-mark lesions on both animals point towards an attack by a predator. Although dog bites might inflict somewhat similar lesions (De Munnynck \& Van de Voorde, 2002), they could be excluded given that (1) stray dogs do not occur in this area; (2) domestic dogs were not allowed on the beach during this period of the year and at the location of the strandings; (3) there were many witnesses at the stranding location; (4) there was only a short time between the strandings and the collection of the carcasses; and (5) the lesions were extensive. We could further exclude terrestrial scavengers or predators as the only one occasionally occurring on Belgian beaches, but only at night time, is the red fox (Vulpes vulpes). The red fox is too small to inflict the lesions present in both porpoises, however, and both harbour porpoises washed ashore during the daytime at locations heavily frequented by tourists and locals. The only wild indigenous animals commonly present in Belgian waters that could have inflicted the types of lesions observed are harbour seals and grey seals. The grey seal (with a weight of up to $350 \mathrm{~kg}$ ) is much larger than the harbour seal (weight up to $130 \mathrm{~kg}$; Reijnders et al., 1997). The measurements of the lesions with traces of apparent canine teeth could be matched with the inter-canine distance in grey seals. This was not the case for harbour seals. Although the largest distances between the canines in the grey seal skulls were associated with either males or with individuals for which no sex was recorded, some females had an inter-canine distance in the maxilla only slightly shorter than the distances measured in the apparent canine teeth lesions. It can be concluded that most likely an adult grey seal inflicted the wounds (although the possibility that more than one seal was involved cannot be excluded). The presence of one or more grey seal bulls or "very large seals" close inshore between July and September 2011 was frequently reported to us by beach lifeguards, for example, at several Belgian coastal communities, constituting additional circumstantial evidence.

Finally, lesions such as bilateral hyphema and severe congestion of the respiratory system associated with severe lung oedema (sero-haemorrhagic froth) are common findings on cetaceans dying from drowning. If other significant lesions are absent, they frequently point towards accidental drowning in fishing gear (bycatch) as the cause of death. In our case, however, the mutilations, 
together with the haemorrhagic nature of many of the lesions and the absence of typical external bycatch marks, makes incidental catch in fishing gear as the cause of death very unlikely. However, drowning could have been caused by the predator. Grey seals frequently dive for more than $10 \mathrm{~min}$ and can stay under water for up to $30 \mathrm{~min}$ (Thompson \& Fedak, 1993). This is much longer than harbour porpoises, which rarely make dives of more than 2 min, although they can stay under water for more than $5 \mathrm{~min}$ (Westgate et al., 1995). As such, a harbour porpoise attacked by a grey seal could well have drowned before succumbing to the injuries inflicted.

\section{Predation or Competitive Interaction?}

As the lesions most probably originated from multiple bites and as large parts of the harbour porpoises' skin and blubber were missing, presumably eaten by the grey seal, we may exclude the possibility of a purely aggressive behaviour towards the harbour porpoises such as observed with bottlenose dolphins killing harbour porpoises (Ross \& Wilson, 1996; Spitz et al., 2006; MacLeod et al., 2007; Barnett et al., 2009). In the latter cases, the harbour porpoises were only attacked and killed but not consumed. The hypothesis of the lethal interaction between the seals and the harbour porpoises described herein should hence be interpreted as either pure predation or as a combination of predation and competitive interaction.

Grey seals can feed on large prey such as salmonids or gadoids. They typically hold the fish with their fore flipper claws while tearing away skin and flesh (Bonner, 1989). Such feeding behaviour can explain the lesions observed in the two porpoises described here. The two slightly curved, parallel incisions on the left side of the head of Animal 1 (Figure 5) could be traces of the end of a tear or bite with a short region between the curved incisions remaining intact and cut or torn off by incisor teeth. Dog bites have been described similarly, with injuries originating from a combination of biting, crushing, and tearing, and resulting in a pattern of punctures, lacerations, and avulsions of skin and soft tissue, with ragged and irregular wound edges (De Munnynck \& Van de Voorde, 2002). Other lesions in the harbour porpoises can be attributed to claw marks originating from the seal holding or pushing the harbour porpoise while tearing away skin and blubber.

Grey seals are opportunistic feeders, taking predominantly fish, cephalopods, and in some cases crustaceans (Pierce et al., 1991; Thompson et al., 1991; Hammond et al., 1994a, 1994b; Ridoux et al., 2007; Brasseur et al., 2010) and even sea birds (Grant \& Bourne, 1971; Lucas \& McLaren,
1988). Individual prey preferences exist, as well as temporal and geographical variations in diet and differences in prey between age groups (Prime \& Hammond, 1990; Hauksson \& Bogason, 1997; Beck et al., 2005; Tucker et al., 2007; Brasseur et al., 2010). Body size dimorphism has been suggested as a factor shaping the differences in diet of males and females of this species (Beck et al., 2007). Grey seals sometimes take the easiest prey available such as fish from static gear and from fish farms (Matthiopoulos et al., 2004; Quick et al., 2004; Königson et al., 2009). Although grey seals are opportunistic feeders, harbour porpoises - to our knowledge — only have been reported as part of their diet on one occasion, with a large grey seal bull "handling" and apparently scavenging on a freshly dead harbour porpoise carcass off the mainland coast of Noord-Holland, The Netherlands, in February 2011 (Camphuysen \& Siemensma, 2011).

The grey seals have presumably only eaten the blubber, possibly due to the fact that the harbour porpoises constituted a prey too large to be eaten entirely. As the fat has the highest energy content, the seals would have had the highest calorific return in the shortest time period, a strategy suggested to be followed - if choice is possible - by grey seals and other marine mammals (Evans, 1987; Bowen et al., 2002; Beck et al., 2007; Breed et al., 2010; Spitz et al., 2010). Polar bears (Ursus maritimus) apparently digest fat more easily than protein (Best, 1985) and also do not usually eat the whole prey. They feed predominantly on the skin and blubber of seals, leaving the fleshy parts of their prey to scavengers (Stirling \& McEwan, 1975; Stirling \& Archibald, 1977).

It further remains a question how a grey seal can catch a harbour porpoise given that harbour porpoises, with maximum recorded swimming speeds of 4.3 to $6.2 \mathrm{~m} / \mathrm{s}$ (Leatherwood et al., 1988; Culik et al., 2001; Otani et al., 2001) can swim faster than grey seals, with maximum recorded swimming speeds of under $3 \mathrm{~m} / \mathrm{s}$ (Thompson \& Fedak, 1993; Gallon et al., 2007). However, harbour porpoises are frequently observed swimming very slowly, or even seemingly resting at the sea surface (Camphuysen \& Peet, 2006) where they may be vulnerable to attacks. Grey seals have been described both as active hunters and as ambush or sit-and-wait predators that remain motionless under water until a suitable prey passes by (Thompson et al., 1991; Thompson \& Fedak, 1993). Also, the two harbour porpoises described herein were in intermediate and poor nutritional conditions, respectively, and, as such, they may have been relatively easy prey items. 
Grey Seal Predation on Harbour Porpoises:

\section{A Common Phenomenon?}

With only the two cases presented here, it remains speculative to conclude whether harbour porpoises are taken by only one or a few grey seal individuals, or if such lethal interaction is a more widespread phenomenon in the large area in which the distribution of both species overlaps. Grey seal predation on harbour porpoises would probably be a recent phenomenon, with apparently not a single case of similar lesions in more than 600 stranded harbour porpoises investigated between January 2000 and September 2011 in Belgium, and with the first descriptions of similarly mutilated harbour porpoises-some possibly also prey of grey seals (yet to be confirmed) - in the Netherlands from 2006 onwards (Leopold \& Camphuysen, 2006; Camphuysen \& Oosterbaan, 2009). Marine carnivores have been demonstrated to exhibit intraspecific variations in diet and foraging tactics (Hoelzel et al., 1989; Harcourt, 1993; Rogers \& Bryden, 1995; Lunneryd, 2001; Bolnick et al., 2003; Estes et al., 2003; Torres \& Read, 2009). An evolution in the foraging tactics of grey seals could have been instigated through a combination of factors. The number of grey seals in colonies bordering the southern North Sea has greatly increased during the last decade (Brasseur et al., 2008; J. Bramley, pers. comm., 5 November 2011). During dedicated surveys of the colonies in the Dutch Delta area (southwestern part of The Netherlands), for instance, a maximum of 45 animals was observed in 2003 (Berrevoets et al., 2005); while in 2011, a maximum of 677 animals was observed (Strucker et al., 2012). Such an increase in numbers may lead to an increased competition for prey and encourage some individuals to explore alternative food items or feeding strategies (Torres et al., 2009). Also, after decades of absence, the harbour porpoise has returned to the southern North Sea (Camphuysen, 1994; SCANS, 2008), and currently there are relatively high densities along the Dutch, Belgian, and northern French shores during part of the year (ASCOBANS, 2011; Haelters et al., 2011; Scheidat et al., 2012).

Other mutilated stranded harbour porpoises in the southern North Sea (The Netherlands, the UK) have kept scientists, administrators, and conservationists puzzled for some years now, and much debate has been ongoing about the possible origin of the mutilations. Proposed "culprits" were ships' propellers, specific gear used to haul gill and tangle nets, fishermen deliberately cutting into bycaught harbour porpoises (Camphuysen \& Oosterbaan, 2009), dredgers, and shark and killer whale predation, but a common understanding does not exist. The true origin of the mutilations in many of the stranded harbour porpoises remained an enigma. Contrary to most cases of stranded and mutilated carcasses, we were able to collect two very fresh harbour porpoises immediately after their stranding, without gulls or other scavengers having picked on them and thus obscuring traces that could have led to the identification of their predator. Although all indirect evidence collected in our study leads to the two harbour porpoises being attacked and killed by a grey seal, we would like to warn against blindly extrapolating this cause of death to all other cases of heavily mutilated harbour porpoises found recently along southern North Sea shores. For example, many occasions of cuts clearly inflicted by fishermen while disentangling bycaught porpoises or when putting bycaught porpoises overboard in order to let carcasses sink out of sight have been reported (Read \& Murray, 2000; Camphuysen et al., 2008; Haelters \& Camphuysen, 2009). Every case should hence be thoroughly described and lesions carefully inspected. Next to investigations of lesions on stranded harbour porpoises, field observations and grey seal stomach content or tissue analysis could provide additional evidence for this behaviour. While DNA analysis of the stomach content of grey seals could reveal the harbour porpoise as part of the diet of a grey seal, traditional scat analysis, based on hard remains of prey, would probably not, since only soft parts, such as blubber, seem to have been consumed.

It remains to be investigated whether harbour porpoises currently might be a regular or occasional prey, if they are taken further offshore as well as close inshore, if they are taken in any weather conditions, if female as well as male grey seals present this behaviour, if grey seals also commonly scavenge on dead harbour porpoises as in one reported case (Camphuysen \& Siemensma, 2011), and if they take bycaught porpoises from static gear. In our opinion, a number of previous cases of mutilated harbour porpoises could be revisited to (partly) answer such questions. Finally, it remains unpredictable what the possible consequences could be of the transfer of disease from one species of marine mammal to another through such behaviour as marine mammals may be susceptible to the same pathogenic agents (Härkonen et al., 2008). If not common, grey seal predation on harbour porpoises certainly seems to be a recent phenomenon in the southern North Sea. It may indicate bottom-up changes in trophic structures instigated by changes in the ecosystem. 


\section{Acknowledgments}

We thank Georges Lenglet (RBINS), Marjan Doom, Patrick Vervaet, Michaël Dekee, Dominick Verschelde (Ghent University, Belgium), Wendy van Bohemen (the Netherlands Centre for Biodiversity Naturalis), Christine Lefèvre (Muséum National d'Histoire Naturelle, Paris), Richard Sabin, Tracy Heath (Department of Zoology, The Natural History Museum, London), and Willy Dabin (Centre de Recherche sur les Mammifères Marins, University of La Rochelle, France) for their assistance in measuring seal skulls. We thank the anonymous reviewers for their useful comments and suggestions on the original manuscript. Finally, we wish to acknowledge the support of the many people involved in the Belgian marine mammal strandings intervention network.

\section{Literature Cited}

ASCOBANS. (2011). Agreement on the Conservation of Small Cetaceans of the Baltic, North East Atlantic, Irish and North Seas: Report of the 18th meeting of the Advisory Committee. Bonn, Germany: ASCOBANS.

Barnett, J., Davison, N., Deaville, R., Monies, R., Loveridge, J., Tregenza, N., \& Jepson, P. D. (2009). Postmortem evidence of interactions of bottlenose dolphins (Tursiops truncatus) with other dolphin species in south-west England. The Veterinary Record, 165, 441444. http://dx.doi.org/10.1136/vr.165.15.441

Beck, C. A., Iverson, S. J., \& Bowen, W. D. (2005). Blubber fatty acids of gray seals reveal sex differences in the diet of a size-dimorphic marine carnivore. Canadian Journal of Zoology, 83(3), 377-388. http://dx.doi.org/10.1139/ Z05-021

Beck, C. A., Iverson, S. J., Bowen, W. D., \& Blanchard, W. (2007). Sex differences in grey seal diet reflect seasonal variation in foraging behaviour and reproductive expenditure: Evidence from quantitative fatty acid signature analysis. Journal of Animal Ecology, 76, 490-502. http:// dx.doi.org/10.1111/j.1365-2656.2007.01215.x

Berrevoets, C. M., Strucker, R. C. W., Arts, F. A., Lilipaly, S. J., \& Meininger, P. L. M. (2005). Watervogels en zeezoogdieren in de Zoute Delta 2003/2004: Inclusief de tellingen in 2002/2003 [Waterbirds and marine mammals in the salt waters of the Delta 2003/2004: Including the counts in 2002/2003] (RIKZ Report 2005.011). Middelburg, The Netherlands: National Institute for Coastal and Marine Management.

Best, R. B. (1985). Digestibility of ringed seals by the polar bear. Canadian Journal of Zoology, 63, 1033-1036. http://dx.doi.org/10.1139/z85-155

Bolnick, D. I., Svanbäck, R., Fordyce, J. A., Yang, L. H., Davis, J. M., Hulsey, C. D., \& Forister, M. L. (2003). The ecology of individuals: Incidence and implications of individual specialization. The American Naturalist, 161(1), 1-28. http://dx.doi.org/10.1086/343878
Bonner, W. N. (1989). The natural history of seals. London: Christopher Helm Publishers.

Bowen, W. D., Tully, D., Boness, D. J., Bulheier, B. M., \& Marshall, G. J. (2002). Prey-dependent foraging tactics and prey profitability in a marine mammal. Marine Ecology Progress Series, 244, 235-245. http://dx.doi. org/10.3354/meps244235

Brasseur, S. M. J. M., Scheidat, M., Aarts, G. M., Cremer, J. S. M., \& Bos, O. G. (2008). Distribution of marine mammals in the North Sea for the generic appropriate assessment of future offshore wind parks (IMARES Report C046/08). Wageningen, The Netherlands: Institute for Marine Resources \& Ecosystem Studies.

Brasseur, S., van Polanen Petel, T., Aarts, G. M., Meesters, E., Dijkman, E., \& Reijnders, P. (2010). Grey seals (Halichoerus grypus) in the Dutch North Sea: Population ecology and effects of wind farms (IMARES Report C137/10). Wageningen, The Netherlands: Institute for Marine Resources \& Ecosystem Studies.

Breed, G. A., Bowen, W. D., \& Leonard, M. L. (2010). Development of foraging strategies with age in a longlived marine predator. Marine Ecology Progress Series, 431, 267-279. http://dx.doi.org/10.3354/meps09134

Camphuysen, C. J. (1994). The harbour porpoise Phocoena phocoena in the southern North Sea. II: A come-back in Dutch coastal waters? Lutra, 37(1), 54-61.

Camphuysen, C. J., \& Oosterbaan, A. (2009). Mysterious mutilations of harbour porpoises: Frequent strandings in The Netherlands, winter 2008/2009, and postscript for the harbour porpoises mutilations: Confusing news items. Sula, 22(1), 25-35.

Camphuysen, C. J., \& Peet, G. (2006). Whales and dolphins of the North Sea. Kortenhoef, The Netherlands: Fontaine Publishers.

Camphuysen, C. J., \& Siemensma, M. L. (2011). Conservation plan for the harbour porpoise Phocoena phocoena in The Netherlands: Towards a favourable conservation status (NIOZ Report 2011-07). Texel, The Netherlands: Royal Netherlands Institute for Sea Research.

Camphuysen, C. J., Smeenk, C., Addink, M., van Grouw, H., \& Jansen, O. E. (2008). Cetaceans stranded in the Netherlands from 1998 to 2007. Lutra, 51(2), 87-122.

Culik, B. M., Koschinski, S., Tregenza, N., \& Ellis, G. M. (2001). Reactions of harbor porpoises Phocoena phocoena and herring Clupea harengus to acoustic alarms. Marine Ecology Progress Series, 211, 255-260. http:// dx.doi.org/10.3354/meps211255

De Munnynck, K., \& Van de Voorde, W. (2002). Forensic approach of fatal dog attacks: A case report and literature review. International Journal of Legal Medicine, 116, 295-300. http://dx.doi.org/10.1007/s00414-0020332-9

Estes, J. A., Riedman, M. L., Staedler, M. M., Tinker, M. T., \& Lyon, B. E. (2003). Individual variation in prey selection by sea otters: Patterns, causes and implications. Journal of Animal Ecology, 72, 144-155. http://dx.doi. org/10.1046/j.1365-2656.2003.00690.x 
Evans, P. G. H. (1987). The natural history of whales and dolphins. London: Academic Press.

Gallon, S. L., Sparling, C. E., Georges, J-Y., Fedak, M. A., Biuw, M., \& Thompson, D. (2007). How fast does a seal swim? Variations in swimming behaviour under differing foraging conditions. The Journal of Experimental Biology, 210, 3285-3294. http://dx.doi.org/10.1242/jeb. 007542

Grant, D. R., \& Bourne, W. R. P. (1971). Grey seals and seabirds. In W. R. P. Bourne (Ed.), Seabird report 1971 (pp. 52-53). Aberdeen, UK: Zoology Department, Aberdeen University.

Haelters, J., \& Camphuysen, K. (2009). The harbour porpoise in the southern North Sea: Abundance, threats and research \& management proposals. Brussels, Belgium: Royal Belgian Institute of Natural Sciences (RBINS/MUMM); and Texel, The Netherlands: Royal Netherlands Institute for Sea Research (NIOZ).

Haelters, J., \& Everaarts, E. (2011). Two cases of physical interaction between white-beaked dolphins (Lagenorhynchus albirostris) and juvenile harbour porpoises (Phocoena phocoena) in the southern North Sea. Aquatic Mammals, 37(2), 198-201. http://dx.doi.org/10. 1578/AM.37.2.2011.198

Haelters, J., Kerckhof, F., Jacques, T. G., \& Degraer, S. (2011). The harbour porpoise Phocoena phocoena in the Belgian part of the North Sea: Trends in abundance and distribution. Belgian Journal of Zoology, 141(2), 75-84.

Hammond, P. S., Hall, A. J., \& Prime, J. H. (1994a). The diet of grey seals around Orkney and other island and mainland sites in north-eastern Scotland. Journal of Applied Ecology, 31, 340-350. http://dx.doi.org/10. 2307/2404548

Hammond, P. S., Hall, A. J., \& Prime, J. H. (1994b). The diet of grey seals in the Inner and Outer Hebrides. Journal of Applied Ecology, 31, 737-746. http://dx.doi. org/10.2307/2404164

Harcourt, R. (1993). Individual variation in predation on fur seals by southern sea lions (Otaria byronia) in Peru. Canadian Journal of Zoology, 71(9), 1908-1911. http:// dx.doi.org/10.1139/z93-273

Härkonen, T., Backlin, B. M., Barrett, T., Bergman, A., Corteyn, M., Dietz, R., . . . Teilmann, J. (2008). Mass mortality in harbour seals and harbour porpoises caused by an unknown pathogen. The Veterinary Record, 162, 555-556. http://dx.doi.org/10.1136/vr.162.17.555

Hauksson, E., \& Bogason, V. (1997). Comparative feeding of grey (Halichoerus grypus) and common seals (Phoca vitulina) in coastal waters of Iceland, with a note on the diet of hooded (Cystophora cristata) and harp seals (Phoca groenlandica). Journal of Northwest Atlantic Fishery Science, 22, 125-135. http://dx.doi.org/ 10.2960/J.v22.a11

Hoelzel, A. R., Dorsey, E. M., \& Stern, S. J. (1989). The foraging specializations of individual minke whales. Animal Behaviour, 38(5), 786-794. http://dx.doi.org/ 10. 1016/S0003-3472(89)80111-3
Jauniaux, T., Garcia Hartmann, M., Haelters, J., Tavernier, J., \& Coignoul, F. (2002). Echouage de mammifères marins: Guide d'intervention et procédures d'autopsie [Marine mammal strandings: A guide on interventions and autopsy procedures]. Annales de Médecine Vétérinaire, 146, 261-276.

Königson, S., Lunneryd, S-G., Stridh, H., \& Sundqvist, F. (2009). Grey seal predation in cod gillnet fisheries in the central Baltic Sea. Journal of Northwest Atlantic Fishery Science, 42, 41-47. http://dx.doi.org/10.2960/J. v42.m654

Leatherwood, S., Reeves, R. R., Perrin, W. F., \& Evans, W. E. (1988). Whales, dolphins, and porpoises of the eastern North Pacific and adjacent Arctic waters: A guide to their identification. New York: Dover Publications.

Leopold, M. F., \& Camphuysen, C. J. (2006). Bruinvisstrandingen in Nederland in 2006: Achtergronden, leeftijdsverdeling, sexratio, voedselkeuze en mogelijke oorzaken [Harbour porpoise strandings in The Netherlands in 2006: Background, age distribution, sex ratio, food choice and possible reasons] (IMARES Report C083/06; NIOZ Report 2006-5). Wageningen, The Netherlands: Institute for Marine Resources \& Ecosystem Studies; and Texel, The Netherlands: Royal Netherlands Institute for Sea Research.

Lockyer, C. (1995). Aspects of the morphology, body fat condition and biology of the harbour porpoise, Phocoena phocoena, in British waters. Report of the International Whaling Commission (IWC) (Special Issue 16), 199-209.

Lockyer, C., Heide-Jørgensen, M. P., Jensen, J., \& Walton, M. J. (2003). Life history and ecology of harbour porpoises (Phocoena phocoena) from West Greenland (Scientific Publications, 5, 177-194). Troms $\varnothing$, Norway: The North Atlantic Marine Mammal Commission (NAMMCO).

Lucas, Z., \& McLaren, I. A. (1988). Apparent predation by grey seals, Halichoerus grypus, on seabirds around Sable Island, Nova Scotia. The Canadian Field-Naturalist, 102, 675-678.

Lunneryd, S. G. (2001). Fish preference by the harbour seal (Phoca vitulina), with implications for the control of damage to fishing gear. ICES Journal of Marine Science, 58, 824-829. http://dx.doi.org/10.1006/jmsc.2001.1073

MacLeod, R., MacLeod, C. D., Learmonth, J. A., Jepson, P. D., Reid, R. J., Deaville, R., \& Pierce, G. J. (2007). Mass-dependent predation risk and lethal dolphin-porpoise interactions. Proceedings of the Royal Society B, 274, 2587-2593. http://dx.doi.org/10.1098/rspb.2007.0786

Matthiopoulos, J., McConnell, B., Duck, C., \& Fedak, M. (2004). Using satellite telemetry and aerial counts to estimate space use by grey seals around the British Isles. Journal of Applied Ecology, 41(3), 476-491. http:// dx.doi.org/10.1111/j.0021-8901.2004.00911.x

Otani, S., Naito, Y., Kato, A., \& Kawamura, A. (2001). Oxygen consumption and swim speed of the harbor porpoise Phocoena phocoena. Fisheries Science, 67(5), 894-898. http://dx.doi.org/10.1046/j.1444-2906. 2001.00338.x 
Pierce, G. J., Miller, A., Thompson, P. M., \& Hislop, J. R. G. (1991). Prey remains in grey seal (Halichoerus grypus) faeces from the Moray Firth, north-east Scotland. Journal of Zoology, 224, 337-341. http://dx. doi.org/10.1111/j.1469-7998.1991.tb04813.x

Prime, J. H., \& Hammond, P. S. (1990). The diet of grey seals from the south-western North Sea assessed from analyses of hard parts found in faeces. Journal of Applied Ecology, 27(2), 435-447. http://dx.doi.org/10. 2307/2404292

Quick, N. J., Middlemas, S. J., \& Armstrong, J. D. (2004). A survey of antipredator controls at marine salmon farms in Scotland. Aquaculture, 230(1-4), 169-180. http:// dx.doi.org/10.1016/S0044-8486(03)00428-9

Read, A. J., \& Murray, K. T. (2000). Gross evidence of human-induced mortality in small cetaceans (NOAA Technical Memorandum NMFS-OPR-15). Washington, DC: U.S. Department of Commerce, National Oceanic and Atmospheric Administration.

Reijnders, P. J. H., Verriopoulos, G., \& Brasseur, S. M. J. M. (1997). Status of pinnipeds relevant to the European Union (IBN Scientific Contributions 8). Wageningen, The Netherlands: IBN-DLO.

Ridoux, V., Spitz, J., Vincent, C., \& Walton, M. (2007). Grey seal diet at the southern limit of its European distribution: Combining dietary analyses and fatty acid profiles. Journal of the Marine Biological Association of the United Kingdom, 87(1), 255-264. http://dx.doi. org/10.1017/S002531540705463x

Rogers, T., \& Bryden, M. M. (1995). Predation of Adélie penguins (Pygoscelis adeliae) by leopard seals (Hydrurga leptonyx) in Prydz Bay, Antarctica. Canadian Journal of Zoology, 73(5), 1001-1004. http://dx.doi.org/ 10.1139/z95-119

Ross, H. M., \& Wilson, B. (1996). Violent interactions between bottlenose dolphins and harbour porpoises. Proceedings of the Royal Society B, 263, 283-286. http:// dx.doi.org/10.1098/rspb.1996.0043

SCANS II. (2008). Small Cetaceans in the European Atlantic and North Sea (Report submitted to the European Commission - LIFE04NAT/GB/000245). Retrieved 11 January 2012 from http://biology.st-and. ac.uk/scans2/inner-finalReport.html.

Scheidat, M., Verdaat, H., \& Aarts, G. (2012). Using aerial surveys to estimate density and distribution of harbour porpoises in Dutch waters. Journal of Sea Research, 69 , 1-7. http://dx.doi.org/10.1016/j.seares.2011.12.004

Spitz, J., Rousseau, Y., \& Ridoux, V. (2006). Diet overlap between harbour porpoise and bottlenose dolphin: An argument in favour of interference competition for food? Estuarine, Coastal and Shelf Science, 70, 259270. http://dx.doi.org/10.1016/j.ecss.2006.04.020

Spitz, J., Mourocq, E., Leauté, J-P., Quéro, J. C., \& Ridoux, V. (2010). Prey selection by the common dolphin: Fulfilling high energy requirements with high quality food. Journal of Experimental Marine Biology and Ecology, 390, 73-77. http://dx.doi.org/10.1016/j. jembe.2010.05.010
Stirling, I., \& Archibald, W. R. (1977). Aspects of predation of seals by polar bears. Journal of the Fisheries Research Board of Canada, 34(8), 1126-1129. http:// dx.doi.org/10.1139/f77-169

Stirling, I., \& McEwan, E. H. (1975). The caloric value of whole ringed seals (Phoca hispida) in relation to polar bear (Ursus maritimus) ecology and hunting behaviour. Canadian Journal of Zoology, 53(8), 1021-1027. http:// dx.doi.org/10.1139/z75-117

Strucker, R. C. W., Arts, F. A., \& Lilipaly, S. (2012). Watervogels en zeezoogdieren in de Zoute Delta 2010/2011 [Waterbirds and marine mammals in the salt waters of the Delta 2010/2011] (RWS Waterdienst BM 12.07). Vlissingen, The Netherlands: Ministerie van Infrastructuur en Milieu, Directoraat-Generaal Rijkswaterstaat.

Thompson, D., \& Fedak, M. A. (1993). Cardiac responses of grey seals during diving at sea. The Journal of Experimental Biology, 174, 139-164.

Thompson, D., Hammond, P. S., Nicholas, K. S., \& Fedak, M. A. (1991). Movements, diving and foraging behaviour of grey seals (Halichoerus grypus). Journal of Zoology, 224, 223-232. http://dx.doi.org/10.1111/j.1469-7998.1991. tb04801.x

Torres, L. G., \& Read, A. J. (2009). Where to catch a fish? The influence of foraging tactics on the ecology of bottlenose dolphins (Tursiops truncatus) in Florida Bay, Florida. Marine Mammal Science, 25(4), 797-815. http://dx.doi.org/10.1111/j.1748-7692.2009.00297.x

Tucker, S., Bowen, W. D., \& Iverson, S. J. (2007). Dimensions of diet segregation in grey seals Halichoerus grypus revealed through stable isotopes of carbon $(\delta 13 \mathrm{C})$ and nitrogen $(\delta 15 \mathrm{~N})$. Marine Ecology Progress Series, 339, 271-282. http://dx.doi.org/10.3354/meps339271

Westgate, A. J., Head, A. J., Berggren, P., Koopman, H. N., \& Gaskin, D. E. (1995). Diving behaviour of harbour porpoises, Phocoena phocoena. Canadian Journal of Fisheries and Aquatic Sciences, 52(5), 1064-1073. http://dx.doi.org/10.1139/f95-104 